\title{
Application of Progesterone Measurement for Age and Body Weight at Puberty, and Postpartum Anestrus in Korean Native Cattle
}

\author{
Chang-Ho SON ${ }^{1)}$, Hyun-Gu KANG ${ }^{1)}$ and Sung-Ho KIM ${ }^{1)}$ \\ ${ }^{1)}$ College of Veterinary Medicine, Chonnam National University, Kwangju 500-757, Republic of Korea
}

(Received 15 March 2000/Accepted 7 August 2001)

ABSTRACT. Studies were conducted in Korean native cattle to determine the age and body weight at puberty, and to determine the postpartum anestrus intervals based on plasma progesterone profiles, rectal palpation, ultrasonography and estrus observation. Korean native cattle reached puberty at 344 days of age and at $188 \mathrm{~kg}$ body weight as determined by plasma progesterone profiles, but estrous behavior was not detected until 3 months later, at a body weight of $215 \mathrm{~kg}$. Prolonged postpartum anestrus occurred in $40 \%$ of smallholders cows, where animals were tethered and fed hay and rice straw, whereas its incidence was only $6.8 \%$ in a well managed herd that was grazed and housed. Plasma progesterone profiles were used to monitor ovarian activity postpartum in standard fed cows $(n=44)$ and restricted fed cows $(n=20)$. In standard fed cows $81.8 \%$ showed luteal activity by 50 days postpartum, compared to $55 \%$ in restricted fed cows. Approximately $40 \%$ of cows in both groups had shown observable estrous behavior by this time. This study indicates that one or more ovulations had occurred before pubertal heifers and postpartum cows showed overt estrous behavior. It was concluded that improved management and feeding practices should result in improved reproductive performance.

KEY WORDS: Korean native cattle (Bos taurus coreanae), postpartum anestrus, progesterone, puberty, ultrasonography.

J. Vet. Med. Sci. 63(12): 1287-1291, 2001

The population of Korean native cattle (Bos taurus coreanae) has increased from 1.6 million in 1990 to 2.3 million in 1998 , but there has been a decrease in the number of farms raising beef from a peak of 0.6 million in 1990 to 0.4 million in 1998. Korean native cattle have traditionally been an important livestock resource in Korea not only for meat production but also for draught power. However, there is an increasing use of mechanical tillers and the traditional farming system is changing rapidly, with fewer smallholders and more large farmers. Korean native cattle are mainly used for beef production at this time, but low production efficiency means that the intercalving interval is more than 365 days.

While analysis of breeding records suggests that the age at puberty in Korean native cattle is about 24 months [13], investigators report that puberty is attained between 14 to 36 months $[4,7,10]$. Poor estrus detection is probably the most important reason for delayed breeding [9, 17], resulting in an extended calving interval [5, 7-9].

There are great variations among individual cows in the age at which heat signs first occur, depending on the level of nutritional intake. Chung et al. [3, 4] reported that the first estrus in heifers fed with a nutritious diet occurred at 14.6 months, when body weight was $265 \mathrm{~kg}$ whereas those fed a restricted ration showed first estrus at 23 months at a body weight of $250 \mathrm{~kg}$.

As a result of the many endocrine studies conducted, a much more accurate picture of the hormonal changes which occur when cows return to full ovarian cyclicity after calving has been built up $[2,14,18]$. The first ovulation usually occurs later after parturition in beef cattle than in dairy cows. It is equally well established that the frequency and intensity of suckling can affect the duration of the postpar- tum period of anestrus. It has been shown that chronic undernutrition and suckling interact to suppress gonadotrophin secretion to very low levels in cows for prolonged periods after calving [19, 25, 27]. This suppression is most likely the result of central inhibition of hypothalamic GnRH release, which, in severely undernourished cows, may be to levels below those necessary for the normal maintenance of pituitary LH and FSH synthesis and storage [26, 27].

A better understanding of the physiological mechanisms controlling reproduction in Korean native cows is required before improvements in reproductive efficiency can be achieved. The purpose of this study was to determine the age at puberty, and the relationships between plasma progesterone profiles and postpartum anestrus in this breed.

\section{MATERIALS AND METHODS}

Experiment I: Study on age and body weight at puberty

Animals: Thirteen heifers from a well managed herd were used. Animals were fed corn silage and hay in a balanced ration (NRC standard). Analyses of feeds supplied to the animals at different stages of growth are presented in Table 1.

Table 1. Analysis of feeds supplied to the heifers at different stages of growth

\begin{tabular}{cccccc}
\hline & \multicolumn{5}{c}{ Body weight $(\mathrm{kg})$} \\
\cline { 2 - 6 } & $<100$ & $100-150$ & $151-200$ & $201-250$ & $251-300$ \\
\hline DM & 2.70 & 4.11 & 5.56 & 6.16 & 7.11 \\
TCP & 0.16 & 0.48 & 0.62 & 0.68 & 0.76 \\
TDN & 0.72 & 2.81 & 3.70 & 4.11 & 4.64 \\
\hline
\end{tabular}


Blood sampling regime: Blood samples were collected from the jugular vein into heparinized containers twice a week from 8 to 24 months of age. The blood was centrifuged at 3,000 $\mathrm{g}$ and the plasma decanted and stored at $-20^{\circ} \mathrm{C}$ until assay. Plasma progesterone concentrations were quantified by radioimmunoassay using antibody coated tubes and ${ }^{125} \mathrm{I}$ progesterone as the radioligand (FAO/IAEA progesterone RIA kits). The sensitivity of the assay was $0.1 \mathrm{ng} / \mathrm{ml}$ and intra- and interassay coefficients of variation were $9.7 \%$ and $13.6 \%$, respectively. Plasma progesterone levels above 1.0 $n \mathrm{~g} / \mathrm{m} l$ were considered as being indicative of luteal activity.

Rectal palpation, estrus observation and body weight: The ovaries and uterus were examined by rectal palpation weekly from 8 to 24 months of age. All heifers were observed for estrous behavior by experienced herdsmen twice a day (08:00 and 18:00 hr) and weighed weekly from 8 to 24 months of age.

Experiment II: Study on postpartum anestrus

Animals:

Standard fed cows (Group 1): Forty-four suckled cows from a well managed herd were used in this study. They were fed corn silage and hay in a balanced ration (NRC standard). Animals were 3 to 9 years of age $($ Mean=5.4) and in their first to seventh parity (Mean=3.5). The analyses of feeds supplied to the animals at pre and postpartum periods are given in Table 2 .

Restricted fed cows (Group 2): Twenty suckled cows from small holders were used in this study. They were fed hay and rice straw but not a balanced ration. Animals were 3 to 11 years of age $($ Mean=5.5) and in their first to sixth parity $($ Mean=2.9).

Blood sampling regime: Blood samples were collected via the jugular vein into heparinized containers, at 3 day intervals from 15 to 80 days postpartum. The blood was centrifuged at 3,000 $\mathrm{g}$ and the plasma decanted and stored at $-20^{\circ} \mathrm{C}$ until analysed for plasma progesterone using the RIA kit as mentioned above. Plasma progesterone levels above $1.0 \mathrm{ng} / \mathrm{m} l$ were considered to be indicative of luteal activity.

Rectal palpation, ultrasonography and estrus observation: The ovaries and uterus were examined by rectal palpation and ultrasonography (EUREKA SA-600, Medison Co, Korea) at 6 day intervals from 15 to 80 days postpartum. Follicles and cystic ovaries were classified as "small", "large", or "cystic" according to their estimated diameters of $<15 \mathrm{~mm}, 15$ to $25 \mathrm{~mm}$ or $>25 \mathrm{~mm}$, respectively. All cows were observed for estrous behavior by experienced herdsmen twice a day (08:00 and 18:00 hr).

\section{RESULTS}

Experiment I: Based on plasma progesterone profiles, mean $( \pm$ SEM) age and body weight at puberty of Korean native cattle were $344 \pm 15$ days and $188.5 \pm 15.6 \mathrm{~kg}$, respectively, compared with $433 \pm 21$ days and $215 \pm 18.2$ $\mathrm{kg}$ as determined by estrus observation.

Representative plasma progesterone profiles illustrating commencement of ovarian activity in Korean native heifers
Table 2. Analysis of feeds supplied to the pre and postpartum cows

\begin{tabular}{ccc}
\hline & $\begin{array}{c}\text { Prepartum }^{\text {a) }} \\
\text { (range) }\end{array}$ & $\begin{array}{c}\text { Postpartum } \\
\text { (range) }\end{array}$ \\
\hline DM & 8.54 & 10.93 \\
& $(7.09-11.06)$ & $(9.8-11.67)$ \\
TCP & 1.03 & 1.38 \\
& $(0.66-1.46)$ & $(0.93-1.65)$ \\
TDN & 4.82 & 6.36 \\
& $(3.73-7.02)$ & $(5.81-6.89)$ \\
\hline
\end{tabular}

a) For 3 months prepartum.

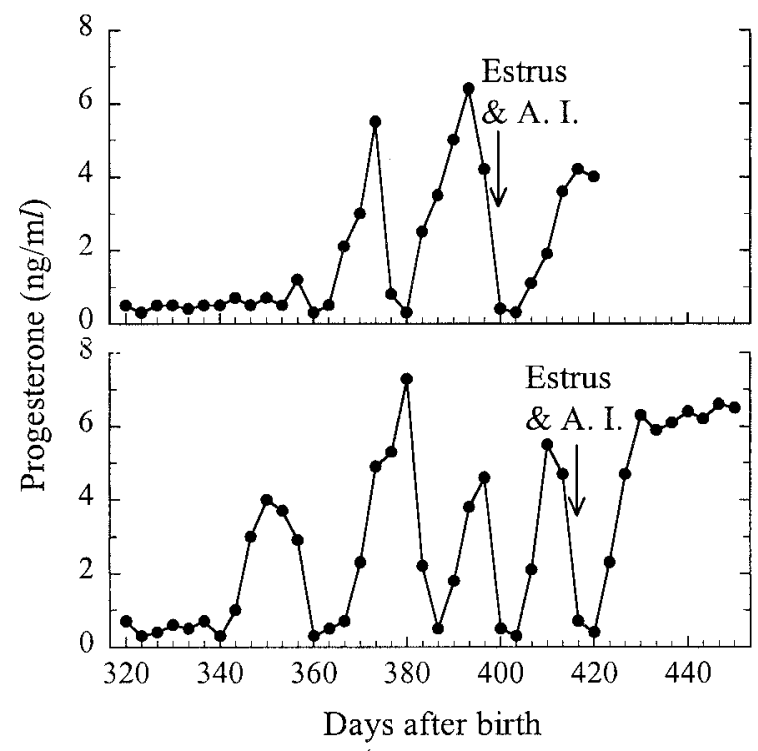

Fig 1. Plasma progesterone profiles in two Korean native heifers during the peri-pubertal period.

Table 3. Percentages of Korean native cattle on two nutritional regimes showing ovarian activity at various times postpartum, as determined by progesterone profiles, rectal palpation and ultrasonography or by estrus observation

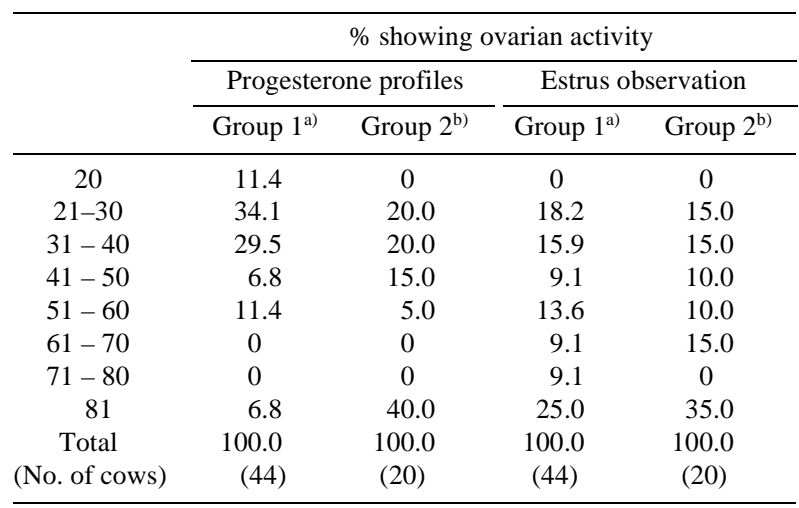

a) Group 1: Standard fed cows. b) Group 2: Restricted fed cows. 
are presented in Fig. 1.

Experiment II: Based on plasma progesterone profiles, $81.8 \%$ of standard fed cows showed luteal activity by 50 days postpartum, compared to $55 \%$ of restricted fed cows. Approximately $40 \%$ of cows of both groups had shown observable estrous behavior by this time (Table 3 ).

Representative plasma progesterone profiles of postpartum cows are presented in Fig. 2, and ovarian status as examined by ultrasonography is presented in Table 4. Four categories of profile were observed. Profile 1 is representative of cows with a normal postpartum anestrus interval (45 days), while Profile 2 and 3 represent those found in cows with more prolonged periods of postpartum anestrus (55 days and 80 days, respectively). These cows were diagnosed as having inactive ovaries or follicular cysts. Cystic wall thickness was $1.2 \mathrm{~mm}$ by ultrasonography and plasma progesterone concentrations were below $0.8 \mathrm{ng} / \mathrm{ml}$. The cows represented by Profile 4 had persistent corpus luteum with pyometra from first ovulation which failed to regress, or luteinized follicle. Cystic wall thickness was $4.8 \mathrm{~mm}$ by ultrasonography and plasma progesterone concentration was $5.2 \mathrm{ng} / \mathrm{ml}$.

Prolonged postpartum anestrus occurred in $40 \%$ of smallholders cows, where animals were tethered and fed hay and rice straw, whereas its incidence was only $6.8 \%$ in the well managed herd that was grazed and housed.

\section{DISCUSSION}

Korean native cattle in this study reached puberty at 344 days of age and at $188 \mathrm{~kg}$ body weight as based on plasma progesterone profiles, whereas estrous behaviors were detected at 433 days of age and at $215 \mathrm{~kg}$ body weight. Based on plasma progesterone profiles and ultrasonography, $81.8 \%$ of standard fed cows had resumed ovarian activity by 50 days postpartum, compared to $55 \%$ of restricted fed cows, but approximately $40 \%$ of cows of both groups had shown observable estrus signs. These results indicate that one or more ovulations had occurred before estrous behavior was observed at the onset of puberty and postpartum.

The effects of nutrition on the onset of puberty in beef

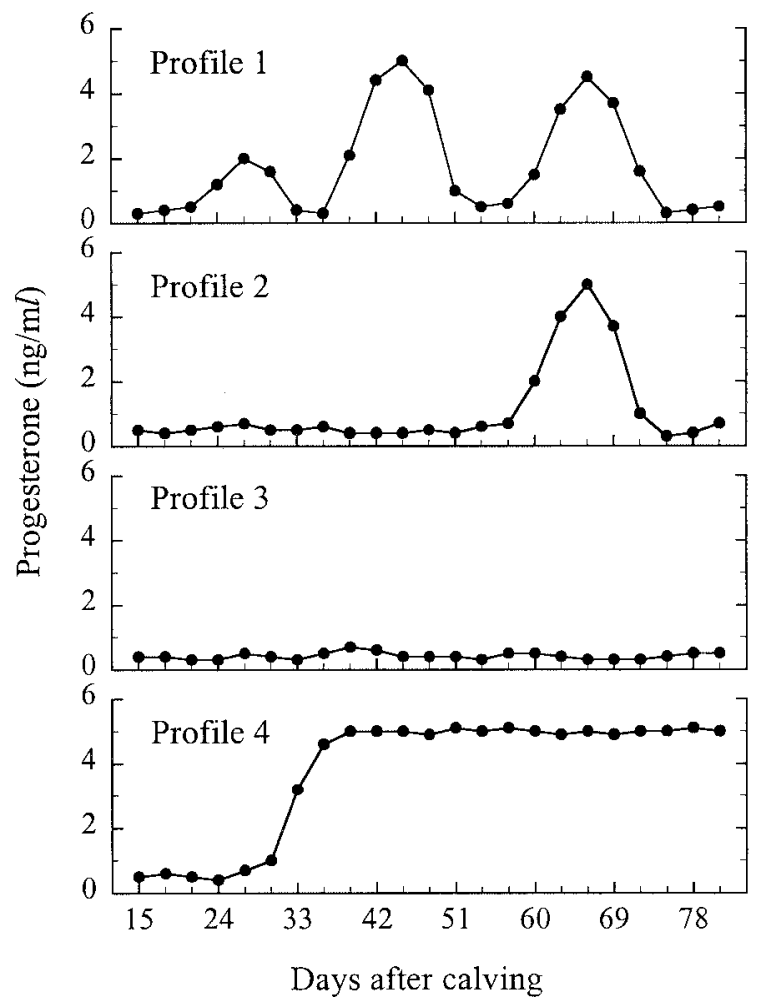

Fig 2. Representative plasma progesterone profiles illustrating different types of postpartum ovarian activity seen in Korean native cattle.

heifers have been reviewed by Schillo et al. [22] and Grings et al. [6]. It was clear in those works that age at puberty is related inversely to plane of nutrition. Bergfeld et al. [1] examined the influence of dietary energy intake on the development of dominant ovarian follicles in prepubertal heifers. They found that heifers in two groups developed ovulatory follicles of similar size at the pubertal ovulation, but the pubertal ovulation was on average 63 days later in heifers fed a lower-energy diet compared with those fed greater amounts of dietary energy.

Table 4. Types of ovarian activity postpartum investigated by plasma progesterone profiles and ultrasonography in Korean native cows

\begin{tabular}{|c|c|c|c|c|c|c|}
\hline \multirow{2}{*}{ Classification } & \multirow{2}{*}{$\begin{array}{l}\text { Pattern of plasma } \\
\mathrm{P}_{4}^{\text {a) }} \text { profiles }\end{array}$} & \multicolumn{2}{|c|}{ No. of cows $(\%)$} & \multirow{2}{*}{$\begin{array}{l}\text { Ovarian state } \\
\text { (Ultrasonography) }\end{array}$} & \multicolumn{2}{|c|}{ No. of cows $(\%)$} \\
\hline & & Group $1^{\text {b) }}$ & Group $2^{\text {c) }}$ & & Group $1^{\text {b) }}$ & Group $2^{\text {c) }}$ \\
\hline Profile I & Normal & 35 (79.5) & $11(55.0)$ & Normal & $35(79.5)$ & $11(55.0)$ \\
\hline Profile II & Cycle delayed & $4(9.0)$ & $1(5.0)$ & Inactive ovaries & $4(9.0)$ & $1(5.0)$ \\
\hline Profile III & $\begin{array}{l}\text { Cycle ceased } \\
\text { with low } \mathrm{P}_{4}^{\text {a) }}\end{array}$ & $3(6.8)$ & $8(40.0)$ & Inactive ovaries & $2(4.5)$ & $7(35.0)$ \\
\hline Profile IV & $\begin{array}{l}\text { Cycle ceased } \\
\text { with high } \mathrm{P}_{4}^{\text {a) }}\end{array}$ & $2(4.5)$ & $0(0)$ & $\begin{array}{l}\text { Follicular cysts } \\
\text { Persistent corpus luteum }\end{array}$ & $\begin{array}{l}1(2.3) \\
1(2.3)\end{array}$ & $\begin{array}{l}1(5.0) \\
0(0)\end{array}$ \\
\hline Total & & $44(100)$ & $20(100)$ & Luteal cyst & $\begin{array}{c}1(2.3) \\
44(100)\end{array}$ & $\begin{array}{l}0(0) \\
20(100)\end{array}$ \\
\hline
\end{tabular}

a) $\mathrm{P}_{4}$ : Progesterone. b) Group 1: Standard fed cows. c) Group 2: Restricted fed cows. 
In Bos taurus cows, puberty is attained at about 7-12 months of age and $250-300 \mathrm{~kg}$ body weight. As first service is usually delayed until about 15 months of age, first calving occurs at $24-36$ months [5]. In Bos indicus cows, puberty generally occurs later and at a higher percentage of adult body weight [20]. Oyedipe et al. [16] reduced the age of puberty by improved protein feeding.

In Korean native cows, Han et al. [7] reported that age at first estrus varied from 12 to 36 months. Chung et al. [4] reported that in heifers kept under similar conditions to those in this study, first estrus was at 14.6 months when body weight was $265 \mathrm{~kg}$, while age at the first calving was 28.9 months at $436 \mathrm{~kg}$ body weight. However, when heifers were fed a restricted diet, first estrus occurred at 23.0 months and a body weight of $250 \mathrm{~kg}$, while age at first calving was 38.9 months. In this study, mean age at puberty of Korean native heifers (11.3 months) as determined by plasma progesterone profiles was less than that reported by Chung et al. [4], and occurred at a lower body weight (188 $\mathrm{kg}$ ). However, when observed estrous behavior was the criterion used, age at puberty (14 months) was similar to that observed by Chung et al. [4] although the body weight at which first estrus was observed $(215 \mathrm{~kg})$ was less. This study indicates that one or more ovulations had occurred before the first visible signs of estrus were observed. This finding may reflect inadequacies in the intensity and timing of estrus detection, or that these ovulations were associated with weak or short-lived estrous signs.

Calving interval is perhaps the major parameter used to assess bovine reproductive efficiency, and individual cows in both dairy and beef herds undergo calving intervals in excess of the average economic optimum of 365 days $[9,11$, 12]. The postpartum acyclic period is of variable length and is affected by various factors, particularly nutritional status, season, suckling and milk yield [15, 21, 23, 24, 26]. Milked dairy cows have been reported to resume ovarian cycles, as determined by milk progesterone measurement, after $24.0 \pm$ 0.6 (SEM) days postpartum [2], whilst the figure for suckling beef cows was $56.9 \pm 2.5$ days [17].

In this study, more standard fed cows $(81.8 \%)$ showed elevation of plasma progesterone indicating an ovulation by 50 days postpartum than did restricted fed cows $(55 \%)$. However, there were no differences in the proportions of cows observed in estrus signs at this time. Since observations for estrus signs were carried out by experienced herdsmen, our results suggest that a high proportion of ovulations occurring during the early postpartum period were associated with little or no estrous behavior, or with short duration of estrus $[10,16]$. The results of this study indicate that postpartum ovarian activity was reestablished later in Korean native cows than in dairy cows, and that the first ovulation postpartum occurred earlier in standard fed cows than in restricted fed cows. Further, these results indicate that plasma progesterone profiles assessed by RIA and ultrasonography can be utilized for monitoring postpartum ovarian activity and may be helpful for the early detection of ovarian dysfunction.
ACKNOWLEDGEMENT. This work was supported by grants from the Korea Science and Engineering Foundation through the Hormone Research Center (1998G0301).

\section{REFERENCES}

1. Bergfeld, E. G. M., Kojima, F. N., Cupp, A. S., Wehrman, M. E., Peters, K. E., Garcia-Winder, M. and Kinder, J. E. 1994. Ovarian follicular development in prepubertal heifers is influenced by level of dietary energy intake. Biol. Reprod. 51: 1051-1057.

2. Bulman, D. C. and Lamming, G. E. 1978. Milk progesterone levels in relation to conception, repeat breeding and factors influencing acyclicity in dairy cows. J. Reprod. Fertil. 54: 447-458.

3. Chung, D. C., Kim, J. K. and Kim, D. C. 1988. The use of radioimmunoassay to monitor reproductive status of Cheju native cattle and the effect of supplementary feeding on reproductive performance. II. Body weight changes, reproductive performance and plasma progesterone concentrations pre and post calving. Korean J. Anim. Reprod. 12: 97-102.

4. Chung, D. C., Kim, J. K., Beak, Y. K. and Moon, S. H. 1986. The use of radioimmunoassay to monitor reproductive status of Cheju native cattle and the effect of supplementary feeding on reproduction. I. Body weight changes, breeding performances and progesterone levels from weaning until first calving. Korean J. Anim. Reprod. 10: 49-57.

5. Dobson, H. and Kamonpatana, M. 1986. A review of female cattle reproduction with special reference to a comparison between buffaloes, cow and Zebu. J. Reprod. Fertil. 77: 1-36.

6. Grings, E. E., Hall, J. B., Bellow, R. A., Short, R. E., Bellows, S. E. and Staigmiller, R. B. 1998. Effect of nutritional management, trace mineral supplementation, and norgestomet implant on attainment of puberty in beef heifers. J. Anim. Sci. 76: 2177-2181.

7. Han, C. K., Lee, N. H., Park, Y. J. and Chung, Y. C. 1989. Survey on the reproductive traits of Korean native cattle. Korean J. Anim. Reprod. 13: 1-6.

8. Imwalle, D. B., Patterson, D. J. and Schillo, K. K. 1998. Effects of melengestrol acetate on onset of puberty, follicular growth, and patterns of luteinizing hormone secretion in beef heifers. Biol. Reprod. 58: 1432-1436.

9. Kang, B. K., Choi, H. S., Choi, S. G., Son, C. H. and Kang, H. G. 1994. Progesterone assays as an aid for improving reproductive efficiency in dairy cattle. IV. Milk progesterone profiles for monitoring postpartum ovarian activity. Korean J. Vet. Res. 34: $881-890$.

10. Kim, J. K. and Kim, S. C. 1980. Studies on the cause of occurrence and the treatment for the reproductive disorders in Jeju native cattle. I. A study on the reproductive status in Jeju native cows. Korean J. Anim. Sci. 22: 161-166.

11. Lamb, G. C., Lynch, J. M., Grieger, D. M., Minton, J. E. and Stevenson, J. S. 1997. Ad libitum suckling by an unrelated calf in the presence or absence of a cow's own calf prolongs postpartum anovulation. J. Anim. Sci. 75: 2762-2769.

12. Lamb, G. C., Miller, B. L., Lynch, J. M., Thomson, K. E., Heldt, J. S., Grieger, D. M. and Stevenson, J. S. 1999. Twice daily suckling but not milking with calf presence prolongs postpartum anovulation. J. Anim. Sci. 77: 2207-2218.

13. Lee, C. G., Wee, S. H. and Park, S. J. 1987. Studies in the purebred Korean native cattle in Chonnam area. I. Reproductive performance. Korean J. Vet. Res. 27: 137-140. 
14. Morino, S., Nakao, T., Tsunoda, N., Kawata, K. and Morimoto, R. 1984. Use of direct enzyme immunoassay of milk progesterone for monitoring postpartum ovarian activity in dairy cows. Jpn. J. Anim. Reprod. 30: 61-67.

15. Nakao, T., Moriyoshi, M. and Kawata, K. 1992. The effect of postpartum ovarian dysfunction and endometritis on subsequent reproductive performance in high and medium producing dairy cows. Theriogenology 37: 341-349.

16. Oyedipe, E. O., Osori, D. I. K., Akerejola, O. and Saror, D. 1982. Effect of level of nutrition on onset of puberty and conception rate of zebu heifers. Theriogenology 18: 525-539.

17. Peters, A. R. 1984. Reproductive activity of the cow in the post-partum period. I. Factors affecting the length of the postpartum acyclic period. Br. Vet. J. 140: 76-84.

18. Peters, A. R. and Riley, G. M. 1982. Milk progesterone profiles and factors affecting post partum ovarian activity in beef cows. Anim. Prod. 34: 145-152.

19. Randel, R. D. 1990. Nutrition and post-partum rebreeding in cattle. J. Anim. Sci. 68: 853-862.

20. Rodrigues H. D., Kinder, J. E. and Fitzpatrick, L. A. 1999. Treatment with 17beta-oestradiol does not influence age and weight at puberty in Bos indicus heifers. Anim. Reprod. Sci. 56: $1-10$.

21. Rukkwamsuk, T., Kruip, T. A. and Wensing, T. 1999. Relationship between overfeeding and overconditioning in the dry period and the problems of high producing dairy cows during the postparturient period. Vet. Q. 21: 71-79.

22. Schillo, K. K., Hall, J. B. and Hileman, S. M. 1992. Effects of nutrition and season on the onset of puberty in the beef heifer. J. Anim. Sci. 70: 3994-4005.

23. Stagg, K., Spicer, L. J., Sreenan, J. M., Roch, J. F. and Diskin, M. G. 1998. Effect of calf isolation on follicular wave dynamics, gonadotropin and metabolic hormone changes, and interval to first ovulation in beef cows fed either of two energy levels postpartum. Biol. Reprod. 59: 777-783.

24. Tjardes, K. E., Faulkner, D. B., Buskirk, D. D., Parrett, D. F., Berger, L. L., Merchen, N. R. and Ireland, F. A. 1998. The influence of processed corn and supplemental fat on digestion of limit-fed diets and performance of beef cows. J. Anim Sci. 76: 8-17.

25. Williams, G. L. 1990. Suckling as a regulator of postpartum rebreeding in cattle: a review. J. Anim. Sci. 68: 831-852.

26. Wright, I. A., Rhind, S. M. and Whyte, T. K. 1992. A note on the effects of pattern of food intake and body condition on the duration of the post-partum anestrus period and $\mathrm{LH}$ profiles in beef cows. Anim. Prod. 54: 143-146.

27. Wright, I. A., Rhind, S. M., Whyte, T. E., Smith A. J., Mcmillen, S. R. and Prado, R. 1990. Circulating concentrations of LH and FSH and pituitary responsiveness to GnRH in intact and ovariectomized suckled beef cows in two levels of body condition. Anim. Prod. 51: 93-101. 